\title{
An Overview of the Facts, Myths and Treatment of the Disease Condition Known as "Epilepsy"
}

\author{
*Okoh-Esene, R.U, ${ }^{1}$ Okogun J.I., ${ }^{2}$ Okwute S.K. And ${ }^{3}$ Thomas S.A. \\ ${ }^{3}$ Sheda Science and Technology Complex (SHESTCO), P.M.B.186, Garki Abuja F.C.T. \\ ${ }^{1}$. National Institute for Pharmaceutical Research and Development Idu, F.C.T. \\ ${ }^{2}$. Chemistry Department, University of Abuja, F.C.T
}

\begin{abstract}
Epilepsy is sometimes called a seizure disorder. It is characterized by recurrent unprovoked seizures. There are over 40 different types of epilepsy and it affects people of all nations and cuts across all races. The Epilepsy Foundation of America defines it as, "a physical condition that occurs when there is a sudden, brief change in how the brain works". Not all seizures are due to epilepsy. There are about fifty million people worldwide at any point in time with this disease and it is not contagious. According to a publication of the National Dissemination Center for Children with Disabilities, 2004, "about two million Americans have epilepsy; of the 125,000 new cases that develop each year, up to 50\% are children and adolescents".

In most cultures, people with epilepsy have been discriminated against, stigmatized,

shunned, or even imprisoned due to misconceptions and ignorance about the true nature of this disease condition. Epilepsy can occur in animals other than humans.

Epilepsy is usually treated with medications prescribed by, a physician, primary caregivers, neurologists, and neurosurgeons. Anticonvulsants can be used to attenuate or abolish seizures. These chemical substances are heterogeneous in nature but they have a common structural feature known as anticonvulsant moiety or nucleus which consists of a nitrogen atom, a carbonyl group and a substituent group. In some cases the implantation of a stimulator of the vagus nerve, or a special diet can be helpful. Neurosurgical operations for epilepsy can be palliative, reducing the frequency or severity of seizures or in some cases an operation can be curative. In traditional systems, herbs have been used to manage and cure epilepsy as well.

Key Words: Epilepsy, seizures, convulsants, contagious, palliative and curative.
\end{abstract}

\section{Introduction}

Over the years, the disease "epilepsy" has been masked in mystery. There have been a lot of misconceptions about the disease, so much so that people run away from victims when they have the attack instead of rendering help. Some people believe that the disease is contagious while others believe it is as a result of either witchcraft or demonic attacks. People with this disease; suffer from undue discrimination by the public instead of being treated with understanding, care, love and encouragement.

The word epilepsy comes from the Greek word epilepsia, which can be broken into two, epi, meaning "upon" and lepsis which means to take hold of, or seizure

(http://en.wikipedia.org/wiki/Epilepsy)[1]. Epilepsy is a disease which occurs when the brain cells are not working properly. It affects people of all nations, socio-economic class, religion and cuts across all races [1].

The Epilepsy Foundation of America defines it as, "a physical condition that occurs when there is a sudden, brief change in how the brain works". When the brain cells are not working properly, a person's consciousness, movement or actions may be altered for sometime. These physical changes are known as epileptic seizures. Therefore, epilepsy is sometimes called a seizure disorder. These seizures are transient signs and or symptoms due to abnormal, excessive or synchronous neuronal activity in the brain. Seizures can either be generalized or partial [1].

In generalized seizures, all brain cells are involved which may be associated with complete loss of consciousness or brief period of fixed staring. With partial seizures, the improper functioning of the brain is limited to one part of the brain. This may cause periods of "automatic behavior" and altered consciousness,

typified by purposeful-looking behavior, like buttoning or unbuttoning a shirt. Though unconscious, this behavior may be repetitive, and is usually not recalled [2].

Not all seizures are due to epilepsy, for instance, many young children have convulsions from fevers (Febrile convulsion) . Other types not classified as epilepsy include those caused as a result of imbalance in body fluids or chemicals or by alcohol or drug withdrawal [1].

There are about fifty million people worldwide at any point in time with this disease [2].

According to a publication of the National Dissemination Center for Children with Disabilities, 2004, "about two million Americans have epilepsy ; of the 125,000 new cases that develop each year, up to $50 \%$ are children and adolescents"[2] . 
In most cultures, people with epilepsy have been discriminated against, stigmatized, shunned, or even imprisoned. In France (Salpetrieri), people found with the disease were treated together with those who were mentally retarded, with chronic syphilis and the criminally insane. In Tanzania, to this day, as with other parts of Africa, it is associated with possession by evil spirits, witchcraft, or poisoning and is believed to be contagious. In ancient Rome, it was known as the Morbus Comitialis (disease of the assembly hall) and was seen as a curse from the gods [1][3].

During this time also, in the ancient Greece and Rome, epilepsy was thought to be a holy disease, it was masked in mystery. People thought that epileptic seizures were due to demonic attacks or visions sent by the gods, so it was known as "Sacred Disease" [2]. HIPPOCRATES in 2008 remarked that, "epilepsy would cease to be considered divine the day it is understood [4].

Among animist Hmong families, for instance, epilepsy was understood as attack by evil spirits, but the victim could become revered as a shaman as a result [1]. Some believe that, epilepsy can only be controlled, but not cured, with medication while others believe the contrary.[3][5].

A resinous secretion, "Castoreum" from the scent glands of the beaver (castor sacks) was used as a remedy [5].Up until well into the 19th century; this substance was widely used as a sedative and a remedy for convulsions and was to be found in every apothecary.

The human skull ("cranum humanum"), was also considered to be an effective remedy for treating the falling sickness throughout many eras: "Scrape a little matter from a human scull and administer this over a period of several months. If the patient is a man, the scull must be that of a woman, and vice versa" (folk remedy from Württemberg)[5].

However, over $30 \%$ of people with epilepsy do not have seizure control even with the best available medications [1]. Surgery may be considered in difficult cases. [1][6]. Sometimes, as a consequence of brain surgery, epileptic seizures may occur in recovering patients. Not all epilepsy syndromes are life long - some forms are confined to particular stages of childhood. Epilepsy should not be understood as a single disorder, but rather as syndromic with vastly divergent symptoms but all involving episodic abnormal electrical activity in the brain [1]. Children may exhibit behaviors that are easily mistaken for epileptic seizures but are not caused by epilepsy. These include:

- Inattentive staring

- Benign shudders (among children younger than age 2, usually when they are tired or excited)

- Self-gratification behaviors (nodding, rocking, head banging)

- Conversion disorder (flailing and jerking of the head, often in response to severe personal stress such as physical abuse).

Epilepsies are classified in five ways:

1. By their first cause (or etiology).

2. By the observable manifestations of the seizures, known as semiology.

3. By the location in the brain where the seizures originate.

4. As a part of discrete, identifiable medical syndromes

5. By the event that triggers the seizures, as in primary reading epilepsy or musicogenic epilepsy

Epilepsy can occur in animals other than humans. There are basically two types of epilepsy in animals, i) Canine epilepsy ii) Feline epilepsy.

Canine epilepsy is usually genetic and affects dogs. The incidences of epilepsy/seizures in the general dog population is put at between $0.5 \%$ and $5.7 \%$ but may be higher in some breeds like Belgian Shepherd varieties[2]. Canine epilepsy is sub divided into three :-i) reactive, ii) secondary and iii) primary.

Reactive epilepsy is caused by metabolic issues, like low blood sugar or kidney or liver failure. ii) There are no known causes of primary or idiopathic epilepsy. iii) If epilepsy is as a result of brain tumor, stroke, or other trauma, it is known as secondary or symptomatic epilepsy [2].

Feline Epilepsy:-These are complex partial seizures which may be shown by a complete lack of movement or by a bizarre behavior accompanied by facial tics or excessive salivation. Cats may experience foaming round the mouth or loss of muscle or bladder control [2]. Epilepsy in cats and other animals is rarer, probably because there are no hereditary components to epilepsy in these animals. Interestingly, Graham Goddard(1967), discovered that in animals, repeated low-level electrical stimulation to some brain sites can result in permanent increases in seizure susceptibility or permanent decrease in seizure threshold (KINDLING).Chemical stimulation can induce seizures and repeated exposure to some pesticides have been shown to induce seizures in both human and animal.

\section{Causes Of Epilepsy}

There are different causes of epilepsy that are common in certain age groups:-

- During the neonatal period and early infancy the most common causes include hypoxic-ischemic encephalopathy, CNS infections, trauma, congenital CNS abnormalities, and metabolic disorders. 
- During late infancy and early childhood, febrile seizures are fairly common. These may be caused by many different things, some thought to be things such as CNS infections and trauma.

- During childhood, well-defined epilepsy syndromes are generally seen.

- During adolescence and adulthood, the causes are more likely to be secondary to any CNS lesion. Further, idiopathic epilepsy is less common. Other causes associated with these age groups are stress, trauma, CNS infections, brain tumors, illicit drug use and alcohol withdrawal.

- In older adults, cerebrovascular disease is a very common cause. Other causes are CNS tumors, head trauma, and other degenerative diseases that are common in the older age group, such as dementia [2].

- Mutations in several genes have been linked to some types of epilepsy. Several genes that code for protein subunits of voltage-gated and ligand-gated ion channels have been associated with forms of generalized epilepsy and infantile seizure syndromes(Miriam H. Meisler and Jennifer A. Kearney,2005)[7].Many ligand - gated ion channels have been linked to some types of frontal and generalized epilepsies. "Epilepsy related mutations in some non-ion channel genes have also been identified"[3].

- Epileptogenesis, is a process through which a normal brain develops epilepsy as a result of an insult [3].

- Brain lesions occurs where there is scar tissue or abnormal mass of tissue in an area of the brain .

Seizure types

Seizure types are organized firstly according to whether the source of the seizure within the brain is localized (partial or focal onset seizures) or distributed (generalized seizures). Partial seizures are further divided on the extent to which consciousness is affected. If consciousness is unaffected, then it is a simple partial seizure; otherwise it is a complex partial(psychomotor) seizure.

A partial seizure may spread within the brain through a process known as secondary generalization.

Generalized seizures are divided according to the effect on the body but all involve loss of consciousness. These include absence(petit mal), myoclonic, clonic, tonic, tonic-clonic (grand mal), and atonic seizures [2].

\section{Types Of Epilepsies}

There are over 40 different types of epilepsy, including: Absence seizures, atonic seizures, benign Rolandic epilepsy, childhood absence, clonic seizures, complex partial seizures, frontal lobe epilepsy, febrile seizures, infantile spasms, , juvenile absence epilepsy, hot water epilepsy, Lennox-Gastaut syprogressive myoclonic epilepsy, reflex epilepsy, Rasmussen's syndrome, simple partial seizures, secondarily generalized seizures, temporal lobe epilepsy, tonic-clonic seizures, tonic seizures, psychomotor seizures, limbic epilepsy, partial-onset seizures, Rett syndrome, generalized-onset seizures, status epilepticus, abdominal epilepsy, akinetic seizures, autonomic seizures, massive bilateral myoclonus, catamenial epilepsy, , gelastic seizures, Jacksonian seizure disorder, motor seizures, multifocal seizures, neonatal seizures, nocturnal seizures, photosensitive epilepsy, pseudo seizures, sensory seizures, subtle seizures, Sylvan seizures, withdrawal seizures and visual reflex seizures, among others.[1][2][6].

Each type of epilepsy presents with its own unique combination of seizure type, typical age of onset, EEG findings, treatment, and prognosis. The most widespread classification of the epilepsies [2] divides epilepsy syndromes by location or distribution of seizures (as revealed by the appearance of the seizures and by EEG) and by cause. Syndromes are divided into localization-related epilepsies, generalized epilepsies, or epilepsies of unknown localization.

Localization-related epilepsies, sometimes termed partial or focal epilepsies, arise from an epileptic focus, a small portion of the brain that serves as the irritant driving the epileptic response. Generalized epilepsies, in contrast, arise from many independent foci (multifocal epilepsies) or from epileptic circuits that involve the whole brain. Epilepsies of unknown localization remain unclear as to whether they arise from a portion of the brain or from more widespread circuits.

Epilepsy syndromes are further divided by presumptive cause: idiopathic, symptomatic, and cryptogenic. In general, idiopathic epilepsies are thought to arise from genetic abnormalities that lead to alteration of basic neuronal regulation [6]. Symptomatic epilepsies arise from the effects of an epileptic lesion, whether that lesion is focal, such as a tumor, or a defect in metabolism causing widespread injury to the brain. Cryptogenic epilepsies involve a presumptive lesion that is otherwise difficult or impossible to uncover during evaluation. Some epileptic syndromes are difficult to fit within this classification scheme and fall in the unknown localization/etiology category[1][2]. People having had only a single seizure, or those with seizures that occur only after specific precipitants ("provoked seizures"), have "epilepsies" that fall into this category. Febrile convulsions are an example of seizures bound to a particular precipitant. Landau-Kleffner syndrome is another epilepsy that, because of its variety of EEG distributions, falls uneasily in clear categories [2][6].

Below are some common seizure syndromes:

Autosomal dominant nocturnal frontal lobe epilepsy (ADNFLE) is an idiopathic localization-related epilepsy that is an inherited epileptic disorder that causes seizures during sleep. Onset is usually in childhood. These seizures arise from the frontal lobes and consist of complex motor movements, such as hand clenching, 
arm raising/lowering, and knee bending. Vocalizations such as shouting, moaning, or crying are also common. ADNFLE is often misdiagnosed as nightmares. ADNFLE has a genetic basis.[1]

Benign centrotemporal lobe epilepsy of childhood or benign Rolandic epilepsy is an idiopathic localizationrelated epilepsy that occurs in children between the ages of 3 and 13 years, with peak onset in pre-pubertal late childhood. Apart from their seizure disorder, these patients are otherwise normal. This syndrome features simple partial seizures that involve facial muscles and frequently cause drooling. Although most episodes are brief, seizures sometimes spread and generalize. These seizures are typically nocturnal and confined to sleep but cease near puberty [3] [7]

Benign occipital epilepsy of childhood (BOEC) is an idiopathic localization-related epilepsy and consists of an evolving group of syndromes. Most authorities include two subtypes, an early subtype with onset between three and five years, and a late onset between seven and 10 years. Seizures in BOEC usually feature visual symptoms such as scotoma or fortifications (brightly colored spots or lines) or amaurosis (blindness or impairment of vision). Convulsions involving one half the body, hemi-convulsions, or forced eye deviation or head turning are common. Younger patients typically experience symptoms similar to migraine with nausea and headache, and older patients typically complain of more visual symptoms [7].

Catamenial epilepsy(CE) is when seizures cluster around certain phases of a woman's menstrual cycle [1]

Childhood absence epilepsy (CAE) is an idiopathic generalized epilepsy that affects children between the ages of 4 and 12 years of age, although peak onset is around five to six years old. These patients have recurrent, brief episodes of unresponsive staring, sometimes with minor motor features such as eye blinking or subtle chewing. The EEG finding in CAE is generalized. Some absence seizures go on to develop generalized tonic-clonic seizures. The children do not usually show cognitive decline or neurological deficits, and the seizures in the majority cease spontaneously with ongoing maturation[1][7].

Dravet's syndrome, previously known as severe myoclonic epilepsy of infancy (SMEI), is a neurodevelopmental disorder beginning in infancy and characterized by severe epilepsy that does not respond well to treatment[1][9]. This syndrome was described by Charlotte Dravet, French psychiatrist and epileptologist (born July 14, 1936). Estimates of the prevalence of this rare disorder have ranged from 1:20,000 to 1:40,000 births, though the incidence may be found to be greater as the syndrome becomes better recognized and new genetic evidence is discovered. It is thought to occur with similar frequency in both genders, and knows no geographic or ethnic boundaries. The cause of Dravet syndrome is highly variable from person to person. Seizures begin during the first year of life and development is normal prior to their onset. In most cases, the first seizures occur with fever and are generalized tonic-clonic (grand mal) or unilateral (one-sided) convulsions. These seizures are often prolonged, and may lead to status epilepticus, a medical emergency. In time, seizures increase in frequency and begin to occur without fever[1][6][8][9].

Frontal lobe epilepsy, usually a symptomatic or cryptogenic localization-related epilepsy, arises from lesions causing seizures that occur in the frontal lobes of the brain. These epilepsies can be difficult to diagnose because the symptoms of seizures can easily be confused with nonepileptic spells and, because of limitations of the EEG, be difficult to "see" with standard scalp EEG[1] [7].

Juvenile absence epilepsy is an idiopathic generalized epilepsy with later onset than CAE, typically in pre-pubertal adolescence, with the most frequent seizure type being absence seizures. Generalized tonic-clonic seizures can occur. Juvenile myoclonic epilepsy (JME) is an idiopathic generalized epilepsy that occurs in patients aged 8 to 20 years. Patients have normal cognition and are otherwise neurologically intact. The most common seizures are myoclonic jerks, although generalized tonic-clonic seizures and absence seizures may occur as well. Myoclonic jerks usually cluster in the early morning after awakening. Interestingly, these patients are often first diagnosed when they have their first generalized tonic-clonic seizure later in life, when they experience sleep deprivation (e.g., freshman year in college after staying up late to study for exams). Alcohol withdrawal can also be a major contributing factor in breakthrough seizures as well. The risk of the tendency to have seizures is lifelong; however, the majority have well-controlled seizures with anticonvulsant medication and avoidance of seizure precipitants [1][7][8].

Ohtahara syndrome is a rare, but severe epilepsy syndrome usually starting in the first few days or weeks of life. The seizures are often in the form of stiffening spasms but other seizures including unilateral ones may be seen. The electroencephalogram (EEG) is characteristic. The prognosis is poor with about half of the infants dying in the first year of life; most if not all surviving infants are severely intellectually disabled and many have cerebral palsy. There is no effective treatment and a number of these children have underlying structural brain abnormalities [1][6] [7]14][16][17].

Primary reading epilepsy is a reflex epilepsy classified as an idiopathic localization-related epilepsy. Reading in susceptible individuals triggers characteristic seizures. Kelly K,Theodore,2005[1] .

Progressive myoclonic epilepsies define a group of symptomatic generalized epilepsies characterized by progressive dementia and myoclonic seizures. Tonic-clonic seizures may occur as well [1][10]. 
Rasmussen's encephalitis is a symptomatic localization-related epilepsy that is a progressive, inflammatory lesion affecting children with onset before the age of 10. Seizures start as separate simple partial or complex partial seizures and may progress to epilepsia partialis continua (simple partial status epilepticus). Neuroimaging shows inflammatory encephalitis on one side of the brain that may spread if not treated. Dementia and hemi paresis are other problems. The cause is hypothesized to involve an immunological attack against glutamate receptors, a common neurotransmitter in the brain.[1][4[10]][17]

Temporal lobe epilepsy (TLE), a symptomatic localization-related epilepsy, is the most common epilepsy of adults who experience seizures poorly controlled with anticonvulsant medications. In most cases, the epileptogenic region is found in the midline (mesial ) temporal structures (e.g., the hippocampus, amygdala, and parahippocampal gyrus). Seizures begin in late childhood and adolescence. If the patient does not respond sufficiently to medical treatment, surgery may be considered [1].

Tuberous Sclerosis (TSC) is a genetic disorder that causes tumors to form in many different organs, primarily in the brain, eyes, heart, kidney, skin and lungs. Several types of brain lesions can occur in individuals with TSC and $60 \%-90 \%$ of people with TSC develop epilepsy [1][10].

West syndrome is a triad of developmental delay, termed, "infantile spasms". Onset occurs between three months and two years, with peak onset between eight and 9 months. West syndrome may arise from idiopathic, symptomatic, or cryptogenic causes. The most common cause is tuberous sclerosis. The prognosis varies with the underlying cause [1]. In general, most surviving patients remain with significant cognitive impairment and continuing seizures and may evolve to another eponymic syndrome, Lennox-Gastaut syndrome [1].

Lennox-Gastaut syndrome (LGS) is a generalized epilepsy that consists of a triad of developmental delay or childhood dementia, mixed generalized seizures. Onset occurs between two and 18 years. This could also be idiopathic, symptomatic, or cryptogenic. Anticonvulsants are usually only partially successful in treatment [1].

\section{Provocants (Triggers )}

Some environmental conditions can lead to an increased likelihood of seizures in someone with epilepsy or in certain syndromes such as :- being asleep, illness, constipation, menstruation, tiredness, sleep deprivation, the transition between sleep and wakefulness (hypnagogia ),stress or anxiety alcohol consumption, pictures with excessive flashing and strobe lights with flashes over5Hz.(http://en.wikipedia.org/wiki/Epilepsy) [1].It is worthy of note that in some epileptic syndromes the provocants are considered to be part of normal daily life like :- reading, hyperventilation, hot water on the head, flashing or flickering of lights. Flickering of lights (photosensitive epilepsy) is a special type of reflex epilepsy which occurs among both patients and the public only between $2-14 \%$ and $0.3-3 \%$ of people with epilepsy and the public respectively.[1][6][7]

The diagnosis of epilepsy usually requires that the seizures occur spontaneously. Nevertheless, certain epilepsy syndromes require particular precipitants or triggers for seizures to occur. These are termed reflex epilepsy. For example, patients with primary_reading epilepsy have seizures triggered by reading. Photosensitive epilepsy can be limited to seizures triggered by flashing lights. Other precipitants can trigger an epileptic seizure in patients who otherwise would be susceptible to spontaneous seizures, for example, children with childhood absence epilepsy may be susceptible to hyperventilation. In fact, flashing lights and hyperventilation are activating procedures used in clinical EEG to help trigger seizures to aid diagnosis [1]. Finally, other precipitants can facilitate, rather than obligately trigger seizures in susceptible individuals. Emotional stress, sleep deprivation, sleep itself, heat stress, alcohol and febrile illness are examples of precipitants cited by patients with epilepsy. Notably, the influence of various precipitants varies with the epilepsy syndrome $[1][6][7][8][10][14]$.

\section{Different Presentations Of Epilepsy}

Epilepsy may present in any of the following ways :- blackouts or periods of confused memory, episodes of staring or unexplained periods of unresponsiveness, involuntary movement of legs and arms; fainting spells with incontinence or followed by excessive fatigue; or odd sounds, distorted perception, episodic feeling of fear that can not be explained [1].

\section{Treatment Of Epilepsy}

Epilepsy is usually treated with medications prescribed by physicians, primary caregivers, neurologists, and neurosurgeons. In some cases the implantation of a stimulator of the vagus nerve, or a special diet can be helpful. Neurosurgical operations for epilepsy can be palliative, reducing the frequency or severity of seizures or in some cases an operation can be curative. In our traditional system, herbs have been claimed to not only manage but cure epilepsy as well. It was not until the second half of the 19th century, when people began to learn more about epilepsy and medicine that drugs were finally found which did have an effect on epileptic 
seizures. The first two substances which were proven to have an anti-epileptic effect and which are still used today, were bromine (first used in 1857) and phenobarbitone (first used in 1912)[ 5 ].

\section{Pharmacologic Treatment.}

In some sufferers of epilepsy, complete relief is experienced when treated with anticonvulsants but if this does not happen then the dose may be increased or another medication is added to the first. The general strategy is to increase the medication dose until either the seizures are brought under control or until doselimiting side effect appears at which point the medication dose is reduced to the highest amount that does not produce undesirable effects[ 1 ]. Anticonvulsants can be used to attenuate or abolish seizures. These chemical substances are heterogeneous in nature but they have a common structural feature known as anticonvulsant moiety or nucleus which consists of a nitrogen atom, a carbonyl group and a substituent group.

Some drugs can be taken daily to prevent seizures or reduce the frequency of their occurrence. These medications are called anticonvulsant or antiepileptic drugs(AEDs). These drugs all have side effects that are dose dependent and others that are idiosyncratic but it is not possible to predict who will suffer from side effects or the dose level the side effect will appear [1][11]. Studies carried out by Schmidt D.(1983), on the, "Reduction of two-drug therapy in intractable epilepsy" showed that in $83 \%$ of patients on a two-drug regime to control their epilepsy could be slowly transferred completely off one of them without any increase in seizure frequency. Unexpectedly, $36 \%$ of the patients showed greater seizure control on a single drug therapy for epilepsy control more than a two drug regime. Side effect were also decreased in those taking a single drug therapy leading to the conclusion that "overall reduction in poly pharmacy may be beneficial for most patients with intractable epilepsy" $[1][11]$.

Therapeutic doses, that is, the dose at which seizures are controlled and side effects are minimal and tolerable may differ considerably in patients. The therapeutic ranges provided by pharmaceutical companies are only ranges and by using blood serum levels and seizure diaries, better seizure control can sometimes be reached. In some cases(such as a seizure flurry) serum levels can be useful to know if the level is very high or low. If after two or three trials of different drugs on a patient and the epilepsy is not brought under control, then the patient's condition is said to be medically refractory[1].

Drugs used only in the treatment of refractory status epilepticus include :- paraldehyde(Paral), midazolam(Versed), and pentobarbital(Nembutal).

Though bromides were the first of the effective anticonvulsant pure compounds, they are no longer used in humans due to their toxicity and low efficacy,Clemmons1997[1][7].

It has also been found that taking valproates while pregnant can have high chances of reduced IQ towards children, Cassels C,2006 and Meador,KI et al (2006.) [3][12].

Diazepam(Valium) and lorazepam(Ativan) are used to abort an active seizure or interrupt a seizure flurry [7].

The following drugs are some of the drugs used to either prevent seizures or reduce seizure frequency :-

carbamazepine(Tegretol),clobazam(frisium),clonazepam(klonopin), ethosuximide (zarontin),felbamate (felbatol), fosphenytoin(cerebyx), gabapentin (neurontin), lamotrigine (lamictal), phenobarbital (luminal), phenytoin (dilantin), pregabalin, (lyrica),topiramate (topamax), valproate semisodium (depakote,eval), zonisamide (zonegram),valproic acid(depakene,convulex), vigabatrin(sabril),primidone (mysoline), oxcarbazepin (trileptal) etc.[1][7].

\section{Surgical Treatment}

Surgical treatment can be an option for epilepsy when an underlying brain abnormality like benign tumor or an area of scar tissue (e.g. hippocampal sclerosis) can be identified [1]. The abnormality must be removable by a neurosurgeon. Surgery becomes an option in patients that do not show adequate control of seizure with even multiple medications. Care must be taken to make sure that the part of the brain that would be removed will not result in unacceptable problem with memory, vision, language or movement which are controlled by different parts of the brain .These tests usually include a neuropsychological evaluation, which sometimes includes an intracarotid sodium amobarbital test (WADA test) -although this invasive procedure is being replaced by non-invasive functional MRI(magnetic resonance imaging) in many centres. RESECTIVE surgery, as opposed to palliative, successfully eliminates or significantly reduces seizures in about $50-90 \%$ of the patients who undergo it [1][2][3] [15][16]. Many patients decide not to undergo surgery owing to fear or the uncertainty of having a brain operation. The most common form of resective surgery is to remove the frontal part of either the right or left temporal lobe. Report from a study carried on 48 patients who underwent this surgery, anterior temporal lobectomy between 1965 and 1974 showed that, 21 patients after their surgeries had had no seizures that caused loss of consciousness since the operation. Three others had been free of seizures for at least nineteen (19) years. The others either had never been totally free of seizures or had died between the time of the surgery and commencement of the study (Kelley K. Theodore,

2005),[1]. 
PALLIATIVE surgery for epilepsy is intended to reduce the frequency or severity of seizures. Examples are callostomy or commissurotomy to prevent seizures from generalizing (spreading to involve the entire brain), which results in a loss of consciousness. This procedure can therefore prevent injury due to the person falling to the ground after losing consciousness. It is performed only when the seizures cannot be controlled by other means. RESECTIVE surgery can be considered palliative if it is undertaken with the expectation that it will reduce but not eliminate seizures[1][2].

HEMISPHERECTOMY is a drastic operation in which most or all of one of the cerebral cortex is removed. It is reserved for people suffering from the most catastrophic epilepsies, such as those due to RASMUSSEN syndrome [2]. If the surgeries performed on very young patients(2-5 years old), the remaining hemisphere may acquire some rudimentary motor control of the ipsilateral body; in older patients, paralysis results on the side of the body opposite to the part of the brain that was removed. Because of these and other side effects it is usually reserved for patients who have exhausted other treatment options[1][2].

KETOGENIC DIETS- These diets are very high in fat and very low in carbohydrate .The ketogenic diet can be effective and is mainly used in children whose epilepsy has not been controlled with medication. Just as with anticonvulsant drugs, the mechanism behind the effect is not fully understood [1][14].This treatment developed at the Mayo clinic in the 1920s was almost forgotten with the discovery of modern antiepileptic arsenal and is available from most pediatric epilepsy centres[14].

John Hopkins,(1998) reported that 50\% or more of patients starting the ketogenic diet reported a decrease in seizures, with $29 \%$ of the patients reporting a $90 \%$ reduction in symptoms, these patients had previously tried an average of six anticonvulsant drugs[1][14].

VAGUS NERVE STIMULATION(VNS):- is a recently developed form of seizure control that makes use of implanted electrical device similar in size, shape, and implant location to a heart peacemaker, which connects to the vagus nerve in the neck[1]. The device once in place can be set to emit electronic pulses, stimulating the vagus nerve at a pre-set intervals and milliamp levels. About $50 \%$ of patients treated in this fashion have shown significant reduction in seizure frequency [1][15][17][18].

RESPONSIVE NEUROSTIMULATOR SYSTEM (RNS) :- tries to reduce seizure frequency . This system relies on a devise implanted just under the scalp. The leads attached to the device implanted in the brain area itself or on the brain surface and are located close to the area where the seizures are believed to start. When a seizure begins, small amounts of electrical stimulations are delivered to suppress it. This system is different from the VNS system, in that the RNS relies on direct brain stimulation and the RNS is a response system. The VNS pulses at predetermined intervals previously set by medical personnel. The RNS system is designed to respond to detected signs that a seizure is about to begin and can record events and allow customized response patterns which may provide greater degree of seizure control[1][2][17].

A SEIZURE RESPONSE DOG; is a sort of service dog which is trained to summon help or ensure personal safety when a seizure occurs. These are not suitable for everyone and not all dogs can be so trained. A dog may develop the ability to sense a seizure before it happens (Barriaux, Marianne,2006),[2].

The Cochrane Collaboration investigated acupuncture, psychological interventions, vitamins and yoga but concluded that there is no reliable evidence to support the use of these as treatment for epilepsy.[1][2] [6] .

\section{HERBAL TREATMENT(Phytotherapy)}

"Phytotherapy" refers to, treatment using plants and parts of plants. This was widely used in the Middle Ages. Indigenous plants which were boiled and taken orally, smoked or inhaled have been used by sufferers of epilepsy to either curtail or cure it permanently [5]. Many epileptics have found permanent cure or effective management for their conditions by using herbal remedies[5][20][24].

Valeria officinalis (Valerian) is currently one of the most popular orthodox anti-spasmodic medication in Russia and Germany. In medicine, the root of $V$. officinalis is intended when Valerian is mentioned. Valerian was first brought to notice as a specific for epilepsy by Fabius Calumna in 1592, he having cured himself of the disease with it [20]. The plant was in such esteem in mediaeval times as a remedy, that it received the name of "All Heal", which is still given it in some parts of the countries.

It is it's anticonvulsant action that has been useful in treating epilepsy [20]. Valerian is a tonic herb which can regulate and balance both extremes. Valerian also stimulates in a way as to improve coordination, increase concentration and energy. This tonic nature of Varian allows it to depress or stimulate where necessary depending on the immediate needs to the nervous system. It has neutrotropic effects directly on higher centres 
of the nervous system. One of the most remarkable aspects of valerian is the almost total lack of toxicity with long term use [20].

Lobelia inflata (Lobelia) historically has been used to treat epilepsy with it's antispasm action. Lobelia siphilitica and Lobelia inflata have basically the same uses. Lobelia was a highly prized medicinal plant and used extensively by Native Americans. It was considered a panacea, being used for just about everything that ailed them. Once it was discovered by Europeans and taken back to England they also used it for many illnesses. Lobelia is still used today as an alternative medicine in many parts of the world. Medical research has found the plants constituents to be Piperidine alkaloids including Lobeline, and other carboxylic acids as well as isolobelanine, gum, resin, chlorophyl, fixed oil, lignin, salts of lime and potassium, with ferric oxide[21]. While at the same time isolobelanine, relaxes the respiratory and neuro-muscular system and acts as a nervine and antispasmodic. It is a most useful systemic relaxant and a holistic combination of stimulation and relaxation. . It is highly toxic and should be administered with caution as an over dose could result among other adverse situations, to death [21].

Panax ginseg (Chinese ginseng) is the most popular medicinal plant of China[22 ]. It is considered tonic to the whole body and has folk use for the treatment of epilepsy and this attribute also applies to mistletoe[22].

Leonurus cardaica(Motherwort) was used to calm epileptics during the $17^{\text {th }}$ century and now is used as a nerve tonic and sedative. Current evidence has confirmed it's benefits as a cardiotonic and it's hot water extract also show sedative and anti-epileptic effects in animals[23].

Artemisia vulgaris (Mugwort) extracts have been confirmed to have sedative effects so it used for treatment of epilepsy. Mugwort (artemisia vulgaris)[5]

In earlier centuries, this was the magical cure-all. Even in orthodox medicine mugwort was believed to be an effective remedy for epilepsy. Absinth, which has in it the amaroids from mugwort flowers, was also used to treat epilepsy[5].

Saliva officinalis(Sage) It is famous throughout history in many different culltures as a miracle herb. A constituent in a Chinese variety, Salvia miltiorchiza may become the source of a new tranquilizing agent but without the side effects of valium. Valium and Librium are benzodiazepines which have been widely prescribed since 1960 to treat epilepsy. Benzodiazepines act on the central nervous system. The herb compound also interacts with the central $\mathrm{B}_{2}$ [24].

Scutellaria lateriflora(scillicap) has been known as a mild and safe nervine. Traditionally it has been used to treat delirium tremens, convulsions, seizures, hysterical states, lockjaw, tremors and epilepsy. It has also been used as a mild sedative for nervousness and insomnia, management of headaches, pain attending teething in children, chorea, neuralgic pain, such as that associated with shingles or sciatica and adjunctive treatment for epilepsy

An outstanding nervine tonic and native to North America, scullcap is a herb that has a distinguished history of medicinal use in the West. Naturopath William Mitchell points out that, "this plant has been used historically by eclectic physicians to treat hysteria, delirium, insomnia, irregular muscular actions, and post-illness nervousness associated with mental and physical exhaustion". In hysteria and convulsions, its action is invaluable. In nervous headaches and in headache arising from incessant coughing and pain, it offers one of the most suitable and reliable remedies[25].

"European and Russian studies have lent support to scullcap's traditional role as a tranquilizer. Their medical experts now accept its potential usefulness as a tranquilizer and sedative. The herb is an ingredient in many European over-the-counter sleep preparations "[25] .

It effectively soothes nervous tension while renewing and revivifying the central nervous system. It has a long history of traditional use for the control and treatment of petit mal seizures. Skullcap may be used to treat any condition associated with exhaustion or depressed states, and can be used with complete safety to ease premenstrual tension. A recent clinical trial demonstrated that the herb is an effective anxiolytic, with a proposed mechanism involving flavonoid interactions with the GABAA receptor [25].

Verbena hastata(blue vervain) is another herb nervine used by many cultures all over the world. It is an American Indian remedy for several diseases including nervous afflictions [26].

Cannabis sativa (Marijuana) has been used by many epileptics as an effective medical treatment of epilepsy. A telephone survey conducted by the ILAE, (2003) showed that more than twice as many epileptics use marijuana than the general population[1][18].

The anticonvulsant properties of marijuana may be the oldest of its known medical benefits. Marijuana was used as a medicine for epilepsy by ancient societies in China, Africa, India, Greece and Rome. Written testimonies of its usefulness, such as the one by Dr. W.B. O'Shaughnessy appeared in Western scientific journals in the 19th century, 1860 [27].

There is some contradictory data about marijuana having both convulsive and anticonvulsive effects. In a few cases, patients have reported experiencing seizures after taking extremely high doses of oral THC 
(Tetrahydrocannabinol, which is a chemical compound found in marijuana). It is for this reason that Marinol is not thought to be safe or effective for controlling epilepsy.

From the mid 1970's and early 1980's, a number of studies using both THC and CBD on animals conducted at the University of Arizona, found that while high doses (near lethal) of THC can trigger convulsions in seizure susceptible animals, the administration of cannabidiol (CBD) in similar or higher does not cause convulsions. The studies concluded that CBD may have powerful anticonvulsant properties which counteract the muscleexciting effects of THC when both compounds are delivered to the body in marijuana. However, some studies in which cannabidiol alone was administered did not yield consistently favorable results. This may point to the fact that the safest and most effective way to treat epilepsy with marijuana is to use all of its compounds together by smoking the plant rather than ingesting its separate ingredients.

In 1975 a report, published in the Journal of the American Medical Association, marijuana smoking controlled the seizures in one 24-year-old patient when combined with conventional anti-epileptic medicine. The subject had experienced incomplete control of his seizures on a regimen of the anticonvulsant drugs, phenobarbital and phenytoin (Dilantin), and complained of grand mal seizure attacks as often as every two months. At the age of 22, he began smoking two to five marijuana cigarettes a day, in conjunction with his regular anticonvulsant medication. At this point, his doctors observed that his epileptic seizures completely stopped.

In 1980, a study appeared in Pharmacology involving 16 patients with grand mal epilepsy who had not responded well to treatment with standard antiepileptic drugs. Each patient was given 200 to 300 milligrams of cannabidiol or a placebo in addition to their antiepileptic drugs. Of the eight patients who received cannabidiol, three experienced complete improvement, two showed partial improvement, two showed minor improvement and one was unchanged. The only adverse side effect was mild sedation. Of the eight placebo patients, only one showed substantial improvement. The other seven patients showed little or no improvement. The report concluded that cannabidiol combined with standard antiepileptic drugs may be effective for controlling epileptic seizures in some patients[27]. However, marijuana still remains illegal .

\section{Legal Implications}

In most countries where there are informed awareness about epilepsy, most people diagnosed with the disease are forbidden by local laws from operating vehicles.

Those who can prove that they have stabilized their condition are however exempted.

In the U.S., they are allowed to drive if their seizures are controlled with treatment and they met with licensing requirement in their state.

In the U.K., it is the responsibility of the patients to inform the Driver and Vehicle Licensing Agency(DVLA) if they have epilepsy [30] .Those continuing to have seizures or who are within 6 months of medication change may have their license revoked [24].If a patient with uncontrolled epilepsy continues to drive to the knowledge of his Doctor, the Doctor after reminding him of his responsibility has a duty to break confidentiality and inform the (DLVA)In many countries, persons with any history of epilepsy are generally disqualified for the medical certifications required for all classes of pilot licenses. In the United States, FAA regulations disqualify applicants for medical certification with a history of epilepsy, although the final decision is made by FAA headquarters, and rare exceptions are sometimes made for persons who have had only an isolated seizure or two in childhood and have remained free of seizures in adulthood without medication [1] [2][7] and [30].

In the United Kingdom, a sub-class of pilots license called the National Private Pilot's License has the same medical requirement standards as the DVLA motoring requirements, hence epilepsy sufferers with one year absence free can, with certain exceptions, fly over UK airspace in certain types of aircraft[30].

Epilepsy Legal Defense Fund of, "The Epilepsy Foundation," is dedicated to advancing the rights of people with epilepsy by changing discriminatory practices, policies and laws through education and increased access to legal services for individuals with epilepsy through a system of managed referral and legal support to a network of attorneys committed to the cause [1][30].

The Epilepsy Foundation is a strong advocate for people living with epilepsy in the United States. The foundation has been active in Congress, the executive branch, and the courts, focusing attention on the needs of those with epilepsy like the availability of affordable quality health care, the search for cure and the protection of civil rights for people with epilepsy [7][30]

In Nigeria there is a near absence of awareness and consideration of this disease condition and its sufferers by the general public and people in Government . There is almost a criminal ignorance and misconception about the disease and the overall needs of the sufferers. 


\section{Educational Implications}

Epilepsy or seizures generally may interfere with a child's ability to learn. It is important for parents to inform teachers and school staff of the child's condition and reactions to drugs and how best to handle him/her in case of any seizures. Depending on the seizure type, some may need additional help to keep them up to date with their mates.

Students with epilepsy are eligible for special education and related services under the, Individuals with Disabilities Act (IDEA) and Individualized Education Program (IEP), in the United States of America [28]. The family and school personnel as a matter of duty work hand in hand to monitor the effectiveness and side effects of drugs on the student. They are expected to inform the doctor if a child's physical or intellectual ability alters(hearing or perception problems).

They must be helped to deal with the psychological and social aspects of this condition, like public misconceptions and fear of seizures, uncertain occurrences, loss of control during episodes, and compliance with medications[30]

The schools and faith based organizations could assist by providing enlightenment programs for staff, students and the general public including information on seizure recognition and first aid [30].

\section{Royalties And Popular Persons (Past/Present) With Epilepsy}

People with epilepsy have excelled in every area, ranging from sports, music and every conceivable aspect of life as can be seen in the table below. Two members of British Conservative Party elected at the 2010 general elections for South Thanet and Blackpool North and Cleveleys, Laura Sandys and Paul Maynar respectively, revealed that they have epilepsy. It is on record that Paul Maynar was the first member of British Parliament to ever reveal that he has epilepsy. Below is a list of few notable persons with epilepsy [33 ].

\begin{tabular}{|c|c|c|}
\hline Name & Life & Comment \\
\hline $\begin{array}{l}\text { Bjørnstjern } \\
\text { Bjørnson }\end{array}$ & $\begin{array}{l}1832- \\
1910\end{array}$ & $\begin{array}{l}\text { Norwegian writer and a } 1903 \text { Nobel Prize in Literature laureate. Developed } \\
\text { focal epilepsy following a stroke in the final year of his life. }\end{array}$ \\
\hline$\underline{\text { Socrates }}$ & $\begin{array}{l}470- \\
399 \\
\text { BC }\end{array}$ & $\begin{array}{l}\text { Ancient Greek philosopher. It is speculated that his daimonion was a simple } \\
\text { partial seizure and that he had temporal lobe epilepsy. }\end{array}$ \\
\hline Julius Caesar & $\begin{array}{l}100-44 \\
\mathrm{BC}\end{array}$ & $\begin{array}{l}\text { Roman military and political leader. He had four documented episodes of what } \\
\text { were probably complex partial seizures. He may additionally have had absence } \\
\text { seizures in his youth. There is family history of epilepsy amongst his ancestors } \\
\text { and descendants. The earliest accounts of these seizures were made by the } \\
\text { biographer Suetonius who was born after Caesar's death. }\end{array}$ \\
\hline$\frac{\text { Elizabeth }}{\text { Monroe }}$ & $\begin{array}{l}1768- \\
1830\end{array}$ & $\begin{array}{l}\text { The wife of James Monroe, fifth President of the United States. Some historians } \\
\text { believe her illness was epilepsy. She is reported to have been prone to } \\
\text { convulsions and was once seriously burnt after falling into a fireplace. }\end{array}$ \\
\hline $\begin{array}{ll}\text { Napoleon } & \text { I } \\
\text { of France }\end{array}$ & $\begin{array}{l}1769- \\
1821\end{array}$ & $\begin{array}{l}\text { French military leader and emperor. A paper by William Osler in } 1903 \text { stated, } \\
\text { "The slow pulse of Napoleon rests upon tradition; it has been suggested that his } \\
\text { epilepsy and attacks of apathy may have been associated features in a chronic } \\
\text { form of Stokes-Adams disease", which implies the seizures were not epileptic } \\
\text { in origin. However, in } 2003 \text {, John Hughes concluded that Napoleon had both } \\
\text { psychogenic attacks due to stress and epileptic seizures. }\end{array}$ \\
\hline Bud Abbott & $\begin{array}{l}1897- \\
1974\end{array}$ & $\begin{array}{l}\text { The straight man in the comedy team of Abbott and Costello. He had epilepsy } \\
\text { all his life, and tried to control and hide it by drinking. }\end{array}$ \\
\hline Ward Bond & $\begin{array}{l}1903- \\
1960\end{array}$ & $\begin{array}{l}\text { A film actor. His epilepsy meant that he was rejected from the draft for World } \\
\text { War II. }\end{array}$ \\
\hline $\begin{array}{l}\text { Danny } \\
\text { Glover }\end{array}$ & $\begin{array}{l}\text { born } \\
1946\end{array}$ & An actor and film director who had epilepsy from age 15 to age 35. \\
\hline $\begin{array}{l}\text { Margaux } \\
\text { Hemingway }\end{array}$ & $\begin{array}{l}1955 \\
1996\end{array}$ & $\begin{array}{l}\text { A film actress and model who had epilepsy from the age of } 7 \text {. Her death was } \\
\text { attributed to suicide by an intentional overdose of phenobarbital, which is an } \\
\text { anticonvulsant. }\end{array}$ \\
\hline Peter Deuel & $\begin{array}{l}1940- \\
1971\end{array}$ & $\begin{array}{l}\text { A television and film actor. His epilepsy is thought to have been brought on } \\
\text { during adolescence by head injuries sustained in an automobile accident. }\end{array}$ \\
\hline $\begin{array}{l}\text { Michael IV } \\
\text { the } \\
\text { Paphlagonian }\end{array}$ & $\begin{array}{l}1010- \\
1041\end{array}$ & $\begin{array}{l}\text { A Byzantine emperor who had frequent tonic clonic epileptic seizures since } \\
\text { adolescence. It was perceived to be demonic possession - punishment for his } \\
\text { sins. }\end{array}$ \\
\hline $\begin{array}{l}\text { Ivan } \mathrm{V} \\
\text { Alekseyevich }\end{array}$ & $\begin{array}{l}1666- \\
1696\end{array}$ & $\begin{array}{l}\text { Older half brother of Russian Tsar Peter the Great. Ivan V was feebleminded, } \\
\text { epileptic, and half-blind. }\end{array}$ \\
\hline
\end{tabular}




\begin{tabular}{|c|c|c|}
\hline $\begin{array}{l}\text { Martha Parke } \\
\text { Custis }\end{array}$ & $\begin{array}{l}1756- \\
1773\end{array}$ & $\begin{array}{l}\text { The daughter of Martha Washington and step daughter of George Washington . } \\
\text { She had seizures from early childhood and died during a seizure, aged } 17 . \\
\text { Unusually for the time, her parents did not hide her epilepsy and encouraged her } \\
\text { to lead a normal life. }\end{array}$ \\
\hline Pope Pius IX & $\begin{array}{l}1792- \\
1878\end{array}$ & Had childhood epilepsy. \\
\hline $\begin{array}{l}\text { Francis } \\
\text { Libermann }\end{array}$ & $\begin{array}{l}1802- \\
1852\end{array}$ & $\begin{array}{l}\text { A Jew who converted to Christianity and studied for priesthood. Epilepsy } \\
\text { prevented his ordination for many years }\end{array}$ \\
\hline $\begin{array}{l}\text { Ida } \\
\text { McKinley }\end{array}$ & $\begin{array}{l}1847- \\
1907\end{array}$ & $\begin{array}{l}\text { First Lady of the United States from } 1897 \text { to } 1901 \text {. Her epilepsy started in } \\
\text { adulthood. Great efforts were made to keep this secret. Her husband, William } \\
\text { McKinley would cover her face with a napkin when she had symptoms at } \\
\text { dinner parties. }\end{array}$ \\
\hline $\begin{array}{l}\text { Antônio } \\
\text { Moreira } \\
\text { César }\end{array}$ & $\begin{array}{l}1850- \\
1897\end{array}$ & $\begin{array}{l}\text { The brutal commander of the third Expedition in the War of Canudos. He had } \\
\text { epilepsy since his } 30 \mathrm{~s} \text {, which worsened on the way to Canudos. He was shot on } \\
\text { the first day of battle and some blame the seizures for his military } \\
\text { misjudgments. }\end{array}$ \\
\hline $\begin{array}{l}\text { Vladimir } \\
\text { Lenin }\end{array}$ & $\begin{array}{l}1870- \\
1924\end{array}$ & $\begin{array}{l}\text { First Premier of the Soviet Union Lenin's final year was characterized by } \\
\text { neurological decline and loss of function. In his last few months, he developed } \\
\text { epilepsy. His seizures worsened and he died in status epilepticus, which had } \\
\text { lasted } 50 \text { minutes. }\end{array}$ \\
\hline Caligula & $\begin{array}{l}12 \text { AD- } \\
41 \text { AD }\end{array}$ & $\begin{array}{l}\text { Roman Emperor. Suetonius states that "As a boy he was troubled with the } \\
\text { falling sickness [epilepsy], and while in his youth he had some endurance, yet at } \\
\text { times because of sudden faintness he was hardly able to walk, to stand up, to } \\
\text { collect his thoughts, or to hold up his head." }\end{array}$ \\
\hline $\begin{array}{l}\text { Harry } \\
\text { Laughlin }\end{array}$ & $\begin{array}{l}1880- \\
1943\end{array}$ & $\begin{array}{l}\text { The director of the American Eugenics Record Office from its inception in } \\
1910 \text { to its closing in 1939. In 1922, he drew up laws for the compulsory } \\
\text { sterilization of various "degenerate" groups, which included those with } \\
\text { epilepsy. }\end{array}$ \\
\hline $\begin{array}{lr}\text { Prince } & \text { Erik, } \\
\text { Duke of } \\
\text { Västmanland }\end{array}$ & $\begin{array}{l}1889- \\
1918\end{array}$ & The youngest son of Gustaf V of Sweden. \\
\hline $\begin{array}{l}\text { Prince John } \\
\text { of the United } \\
\text { Kingdom }\end{array}$ & $\begin{array}{l}1905- \\
1919 \\
\end{array}$ & $\begin{array}{l}\text { The youngest son of King George V, John had epilepsy from the age of } 4 \text { until } \\
\text { his death after a seizure aged } 13 \text {. }\end{array}$ \\
\hline Jimmy Reed & $\begin{array}{l}1925- \\
1976\end{array}$ & $\begin{array}{l}\text { An American blues singer. His diagnosis of epilepsy in } 1957 \text { was delayed due } \\
\text { to an assumption that these were attacks of delirium tremens. He died after an } \\
\text { epileptic seizure aged } 51 \text {. }\end{array}$ \\
\hline Ian Curtis & $\begin{array}{l}1956- \\
1980\end{array}$ & $\begin{array}{l}\text { The vocalist and lyricist of the band Joy Division was diagnosed with epilepsy } \\
\text { aged 22. The cover of their album Unknown Pleasures resembles an EEG } \\
\text { tracing, but is actually the tracings of the radio emissions of a pulsar. The } \\
\text { condition was a primary cause of his suicide in } 1980 \text {. }\end{array}$ \\
\hline Hikari Oe & $\begin{array}{l}\text { born } \\
1963\end{array}$ & $\begin{array}{l}\text { A Japanese composer who has autism , epilepsy and mental retardation and } \\
\text { has created two successful classical-music CDs. He is the son of Kenzaburo Oe, } \\
\text { the Japanese novelist who won the } 1994 \text { Nobel Prize in Literature. }\end{array}$ \\
\hline Prince & $\begin{array}{l}\text { born } \\
1958\end{array}$ & $\begin{array}{l}\text { American singer, who had epilepsy as a child and sang about his condition in } \\
\text { the song 'The Sacrifice of Victor'. }\end{array}$ \\
\hline $\begin{array}{l}\text { Florence } \\
\text { Griffith } \\
\text { Joyner }\end{array}$ & $\begin{array}{l}1959- \\
1998\end{array}$ & $\begin{array}{l}\text { An athlete with world records in the } 100 \mathrm{~m} \text { and } 200 \mathrm{~m} \text {. She developed seizures } \\
\text { in her thirties, possibly due to a cavernous angioma that was discovered on } \\
\text { autopsy. She died from asphyxiation after a grand mal seizure while asleep. }\end{array}$ \\
\hline Wally Lewis & $\begin{array}{l}\text { born } \\
1959\end{array}$ & $\begin{array}{l}\text { One of Australia's greatest rugby league players, national team captain 1984-89. } \\
\text { After retirement from the sport, he became a television sports presenter, but } \\
\text { became disoriented during a live-to-air broadcast in late 2006. Medical tests } \\
\text { revealed that he had epilepsy. }\end{array}$ \\
\hline $\begin{array}{l}\text { Grover } \\
\text { Cleveland } \\
\text { Alexander }\end{array}$ & $\begin{array}{l}1887- \\
1950\end{array}$ & $\begin{array}{l}\text { A major league baseball pitcher who tried to hide his epilepsy with alcohol, } \\
\text { which was at the time considered to be a more socially acceptable problem. Ty } \\
\text { Cobb said he "suffered hell on the field." }\end{array}$ \\
\hline Tony Greig & $\begin{array}{l}\text { born } \\
1946\end{array}$ & $\begin{array}{l}\text { A former cricketer and commentator who is involved with Epilepsy Action } \\
\text { Australia. He had his first seizure, aged 14, during a tennis game but has }\end{array}$ \\
\hline
\end{tabular}




\begin{tabular}{|c|c|c|}
\hline & & successfully controlled his epilepsy with medication. \\
\hline Paul Wade & $\begin{array}{l}\text { born } \\
1962\end{array}$ & $\begin{array}{l}\text { Former Australian national football player and television sports commentator. } \\
\text { Wade had epilepsy all his life but was only diagnosed as an adult. He kept it } \\
\text { secret until he had a seizure on live television in 2001. Drugs weren't } \\
\text { controlling the seizures so, in 2002, he had surgery to remove a scar in his } \\
\text { brain. He is now seizure free. }\end{array}$ \\
\hline Terry Marsh & $\begin{array}{l}\text { Born } \\
1958\end{array}$ & $\begin{array}{l}\text { A boxer who was IBF world light-welterweight champion. His diagnosis of } \\
\text { epilepsy in 1987, aged } 29 \text {, forced him into retirement undefeated. }\end{array}$ \\
\hline $\begin{array}{l}\text { Marion } \\
\text { Clignet }\end{array}$ & $\begin{array}{l}\text { Born } \\
1964\end{array}$ & $\begin{array}{l}\text { A Franco-American cyclist who found that she has epilepsy at the age of } 22 \text {. } \\
\text { She was shunned by the U.S. cycling federation and subsequently rode in the } \\
\text { colors of France. She has since won } 6 \text { world titles, } 2 \text { Olympic silver medals, as } \\
\text { well as numerous races world wide. }\end{array}$ \\
\hline $\begin{array}{l}\text { Maggie } \\
\text { McEleny }\end{array}$ & $\begin{array}{l}\text { Born } \\
1965\end{array}$ & $\begin{array}{l}\text { Four times British Paralympic swimmer, winning } 3 \text { gold, } 5 \text { silver and } 7 \text { bronze. } \\
\text { McEleny has paraplegia and epilepsy. In 2000, she was made an MBE and } \\
\text { awarded a Golden Jubilee Award by the British Epilepsy Association. }\end{array}$ \\
\hline $\begin{array}{l}\text { Neil } \\
\text { Abercrombie }\end{array}$ & $\begin{array}{l}\text { Born } \\
1937\end{array}$ & $\begin{array}{l}\text { A United States congressmanwho campaigns for increased funding for epilepsy } \\
\text { research. He was diagnosed with epilepsy in his early thirties. }\end{array}$ \\
\hline $\begin{array}{l}\text { Rudi } \\
\text { Dutschke }\end{array}$ & $\begin{array}{l}1940- \\
1979\end{array}$ & $\begin{array}{l}\text { A prominent spokesperson of the left-wing German student movement of the } \\
\text { 1960s. An assassination attempt in 1968, when he was shot twice in the head, } \\
\text { left him partially blind and with frequent epileptic attacks. He drowned in the } \\
\text { bathtub after suffering a seizure }\end{array}$ \\
\hline$\underline{\text { Tony Coelho }}$ & $\begin{array}{l}\text { Born } \\
1942\end{array}$ & $\begin{array}{l}\text { A former United States congressman who developed epilepsy aged 16, possibly } \\
\text { as a result of an earlier head injury. This led to rejection by his family and the } \\
\text { Jesuits for "possession by the devil". }{ }^{[37} \text { He has campaigned as a congressman } \\
\text { for disabled rights and chairs the Epilepsy Foundation's national board of } \\
\text { directors. }\end{array}$ \\
\hline 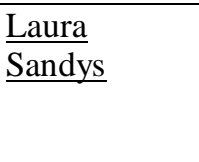 & $\begin{array}{l}\text { Born } \\
1964\end{array}$ & $\begin{array}{l}\text { British Conservative Party politician. She was elected at the } 2010 \text { general } \\
\text { election as the Member of Parliament (MP) for South Thanet. She revealed in } \\
\text { parliament in October } 2010 \text { that she had epilepsy, but had been seizure-free for } \\
\text { seven years. }\end{array}$ \\
\hline Paul Maynar & $\begin{array}{l}\text { Born } \\
1975\end{array}$ & $\begin{array}{l}\text { British Conservative Party politician. He was elected at the } 2010 \text { general } \\
\text { election as the Member of Parliament (MP) for Blackpool North and Cleveleys. } \\
\text { He was the first British MP ever to reveal that he has epilepsy. In 2010, he was } \\
\text { appointed vice-president of the charity Epilepsy Action. }\end{array}$ \\
\hline
\end{tabular}

This list is by no means exhaustive, there are many more known persons not documented in this write up, excluding those unknown because the sufferers have kept their conditions secret or hidden under "more socially acceptable" conditions. Either way, epilepsy is real and is no respecter of age, gender, class, religion, race, educational or family background. It can either be acquired genetically or during the course of one's life, any one, so it deserves more attention than it is currently getting especially in Africa and Nigeria in particular. Stigma continues to this day, in both the public and private spheres, but polls suggest that it is decreasing with time, at least in the developed world[2].

Herbs are being exploited for possible use for the management or as cure for the disease.

\section{References}

[1] Epilepsy-Wikipedia,the free encyclopedia(2008). http://en.wikipedia.org/wiki/Epilepsy

[2] Cascino GD (1994). "Epilepsy: contemporary perspectives on evaluation and treatment". Mayo Clinic Proc 69: 1199-1211. http://en.wikipedia.org/wiki

[3] Engel J Jr.(1996). "Surgery for seizures". NEJM 334 (10): 647-652.

[4] Hippocrates ( ) Hippocrates-wikiquote http://en.wikiquote.org/wiki/Hippocrates

[5] Artemesia Vulgaris: Epilepsy: Attempts at treating: drugs, surgery, history. Epilepsy museum. kork www.epilepsiemuseum.de/alt/body_therapeen.html.

[6] Epilepsy Foundation of America, Epilepsy $\quad$ Syndromes(2011). $\quad$ Available from http://www.epilepsyfoundation.org/about/types/syndromes/index.cfm .

[7] Kuzniecky R (1987). "Benign occipital epilepsy: a family study". Epilepsia 24: 346-350.

[8] Loiseau P, Duche B, Cordova S, et al. (1988). "Prognosis of benign childhood epilepsy with centro-temporal spikes. A follow-up of 168 patients". Epilepsia 29 (3): 229-235.

[9] Dravet C (1978). Les epilepsies graves de l'enfant. Vie Médicale 8: 543-548

[10] Panayiotopoulos CP (2000). "Benign childhood epileptic syndromes with occipital spikes: New classification proposed by the ILAE". J Child Neurol 15 (8): 548-552.

[11] Schmidt D(1983). "Reduction of Two- Drug Therapy in Intractable Epilepsy". Epilepsia 24(3):368-376 
[12] Cassels, Caroline(2008).NEAD :In Utero Exposure To Valproate Linked to Poor Cognitive Outcomes in Kids http://www.medscape.com/viewarticle/549073

[13] The Ring chromosome 20 foundation 20http://www.ring20.org/what-is-r20.php

[14] Olson D (November 1, 2008). "Differentiating Epileptic Seizures From Nonepileptic Spells". Consultant for Pediatricians http:www.consultative.com/Consultant-for-pediatricians/article/1145470/140577.

[15] Epilepsy: aetiogy [sic], epidemiology and prognosis". World Health Organization. February 2001. Archived from the original on 2007-05-18. http://web.archive.org/web/20070518073641/http://www.who.int/mediacentre/factsheets/fs165/en/. Retrieved 2007-0614

[16] The National Society for Epilepsy (2009), What is Epilepsy?. Available from http://www.epilepsynse.org.uk/AboutEpilepsy/Whatisepilepsy .

[17] Bertrand D, Picard F, Le Hellard S, Weiland S, Favre I, Phillips H, et al. (2002). "How mutations in the nAChRs can cause ADNFLE epilepsy.". Epilepsia 43 Supple 5: 112-122.

[18] Fisher R, van Emde Boas W, Blume W, Elger C, Genton P, Lee P, Engel J (2005). "Epileptic seizures and epilepsy: definitions proposed by the International League Against Epilepsy (ILAE) and the International Bureau for Epilepsy (IBE)". Epilepsia 46 (4): 470-2. http://www.blackwell-synergy.com/doi/full/10.1111/j.0013-9580.2005.66104.x.

[19] (Aicardi J and Ohtahara S. Severe neonatal epilepsies with suppression-burst pattern. Epileptic Syndromes in Infancy, Childhood and Adolescence (4th edition) Eds Roger J, Bureau M, Dravet C,Genton P, Tassinari C, and Wolf P. John Libbey Eurotext 2005

[20] Valeriana Officinalis -Valeriana-Treats Epilepsy-Diet and Health.net http://www.diet-and health.net/Naturopathy/Valerian.html

[21] Lobelia Herbal uses(1997), http://www.altnature.com/gallery/Blue_Lobelia.html

[22] Ginseng Epilepsy(2007).http://www.epilepsy.com/epilepsy/alternative_ginseng

[23] Leonurus cardaica( 2010), Common Motherwort Leorurus cardiaca .Motherwort Herb Extract. motherwort herb extract.. MDidea. Extr- http://www.midea.com/products/news/news031.html

[24] Salvia officinalis(2011).wikipedia the free encyclopedia http://en.wikipedia.org/wiki/salvia_officinalis

[25] Scutellaria Officialis. GreenOrganic.ca: :Herbal Pharmacy:: Nervous system .scullcap(Scutelleria lateriflora http://www.greenorganic.ca/scullcap-scutellaria-sculellaria-lateflora.html.

[26] Blue Vervain Verbena Hastata(2005).http://www.annesremedy.com/herb_detail 121.php

[27] Marijuana EPILEPSY:http.//www.mellogold.com/medical/epilepsy.html.

[28] Disability information: Epilepsy (FS6)(2004), http://www.nichy.org/pubs/factshe/fs6txt.hxml

[29] Marcello Spinell (2001), Herbal Medicines and Epilepsy: The Potential for Benefit and Adverse Effects. http://Professionals.epilepsy.com/page/e_b_herbal medicines.html

[30] Epilepsy Action (2009), Driving law relating to seizures. Available from http://www.epilepsy.org.uk/info/driving/lawseizure

[31] Epilepsy Society (2011), What is Available http://www.epilepsysociety.org.uk/AboutEpilepsy/Whatisepilepsy(Accessed on 06 August 2011).

[32] McMahon, B.T.; L.R. Shaw (September 1999). "Chapter Six: Tony Coelho". Enabling Lives: Biographies of Six Prominent Americans with Disabilities. CRC Press. ISBN 0-8493-0351-6.

[33] List of People With Epilepsy(2006) "Coaching With Surgical Precision". Australian Headlines (National Epilepsy Magazine). Epilepsy Action (Australia). 2004. Archived from the original on 2006-08-29.

[34] James Raia (2007). "Marion Clignet: The Life \& Times Of An Epileptic Cycling Champion". http://www.byjamesraia.com/articles/18/1/Marion-Clignet-The-Life-amp-Times-Of-An-Epileptic-Cycling-Champion/Page1.html.

[35] Cycling News (2008)."Marion Clignet's Back". http://autobus.cyclingnews.com/teamprofiles/2000/clingon00.shtml. 